\title{
Psychedelics and Religious Experience
}

\author{
Alan Watts*
}

$\mathrm{T}$ HE EXPERIENCES resulting from the use of psychedelic drugs are often described in religious terms. They are therefore of interest to those like myself who, in the tradition of William James, ${ }^{1}$ are concerned with the psychology of religion. For more than thirty years I liave been studying the causes, the consequences, and the conditions of those peculiar states consciousness in which the individual discovers himself to be one continuous process with God, with the Universe, with the Ground of Being, or whatever name he may use by cultural conditioning or personal preference for the ultiniate and eternal reality. We have no satisfactory and definitive name for experiences of this kind. The terms "religious experience," "mystical experience," and "cosmic consciousness" are all too vague and compreliensive to denote that specific mode of consciousness which, to those who have known it, is as real and overwhelming as falling in love. This Article describes such states of consciousness as and when induced by psychedelic drugs, although they are virtually indistinguishable from genuine inystical experience. The Article then discusses objections to the use of psychedelic drugs which arise mainly from the opposition between niystical values and the traditional religious and secular values of Western society.

\section{I}

THE PSYCHEDEIIC EXPERIENCE

The idea of mystical experiences resulting from drug use is not readily accepted in Western societies. Western culture has, historically, a particular fascination with the value and virtue of man as an individual, selfdetermiming, responsible ego, controlling himself and his world by the power of conscious effort and will. Nothing, then, could be more repugnant to this cultural tradition than the notion of spiritual or psychological growth through the use of drugs. A "drugged" person is by defimition dimmed in consciousness, fogged in judgment, and deprived of will. But not all psychotropic (consciousness-changing) chemicals are narcotic and soporific, as are alcohol, opiates, and barbiturates. The effects of what are

*S.T.M., D.D. Philosopher and Author, with special interests in the psychology of religion and comparative religion. Former research fellow in Social Relations, Harvard University, and twice recipient of research fellowships from the Bollingen Foundation. Publications include: The Wisdom of Insecurity; Myth \& Ritual in Christianity; The Way of Zen; Nature, Man \& Woman; Psychotherapy East \& West; The Joyous Cosmology; Beyond Theology.

1 See W. Jaxtes, The Varteties of Rechgiods Experience (1911). 
now called psychedelic (mind-manifesting) chemicals differ from those of alcohol as laughter differs from rage or delight from depression. There is really no analogy between being "high" on LSD and "drunk" on bourbon. True, no one in either state should drive a car, but neither should one drive while reading a book, playing a violin, or making love. Certain creative activities and states of mind demand a concentration and devotion which are simply incompatible with piloting a death-dealing engine along a highway.

I nyself have experimented with five of the principal psychedelics: LSD-25, mescaline, psilocybin, dimethyl-tryptamine (DMT), and cannabis. I have done so, as William James tried nitrous oxide, to see if they could help me in identifying what might be called the "essential" or "active" ingredients of the mystical experience. For almost all the classical literature on mysticism is vague, not only in describing the experience, but also in showing rational connections between the experience itself and the various traditional methods recommended to induce it-fasting, concentration, breathing exercises, prayers, incantations, and dances. A traditional master of Zen or Yoga, when asked why such-and-such practices lead or predispose one to the mystical experience, always responds, "This is the way my teacher gave it to me. This is the way I found out. If you're seriously interested, try it for yourself." This answer hardly satisfies an impertinent, scientifically-minded, and intellectually curious Westerner. It reminds him of archaic medical prescriptions compounding five salamanders, powdered gallowsrope, three boiled bats, a scruple of phosphorus, three pinches of henbane, and a dollop of dragon dung dropped when the moon was in Pisces. Maybe it worked, but what was the essential ingredient?

It struck me, therefore, that if any of the psychedelic chemicals would in fact predispose iny consciousness to the mystical experience, I could use them as instruments for studying and describing that experience as one uses a microscope for bacteriology, even though the microscope is an "artificial" and "unnatural" contrivance which might be said to "distort" the vision of the naked eye. However, when I was first invited to test the mystical quahities of LSD-25 by Dr. Keith Ditman of the Neuropsychiatric Chnic at UCLA Medical School, I was unwilling to believe that any mere chemical could induce a genuine mystical experience. At most it might bring about a state of spiritual insight analogous to swimming with water wings. Indeed, my first experiment with LSD-25 was not mystical. It was an intensely interesting aesthetic and intellectual experience which challenged my powers of analysis and careful description to the utmost.

Some months later, in 1959, I tried LSD-25 again with Drs. Sterling Bunnell and Michael Agron, who were then associated with the Langley- 
Porter Clinic in San Francisco. In the course of two experiments I was amazed and somewhat embarrassed to find myself going through states of consciousness which corresponded precisely with every description of major niystical experiences that I had ever read." Furthermore, they exceeded both in depth and in a pecuhar quality of unexpectedness the three "natural and spontaneous" experiences of this kind which had happened to me in previous years.

Through subsequent experimentation with LSD-25 and the other chemicals nanied above (with the exception of DMT, which I find amusing but relatively uninteresting) I found I could move with ease into the state of "cosmic consciousness," and in due course became less and less dependent on the chemicals themselves for "tuning-in" to this particular wave-length of experience. Of the five psychedelics tried, I found that LSD-25 and cannabis suited my purposes best. Of these two, the lattercannabis-which I had to use abroad in countries where it is not outlawed, proved to be the better. It does not induce bizarre alterations of sensory perception, and medical studies indicate that it may not, save in great excess, have the dangerous side effects of LSD, namely chroniosomal damage and possible psychotic episodes.

For the purposes of this study, in describing my experiences with psychedelic drugs, I avoid the occasional and incidental bizarre alterations of sense perception which psychedelic chemicals may induce. I am concerned, rather, with the fundamental alterations of the yormal, sociallyinduced consciousness of one's own existence and relation to the external world. I am trying to delineate the basic principles of psychedelic awareness. But I must add that I can speak only for myself. The quality of these experiences depends considerably upon one's prior orientation and attitude to life, although the now voluminous descriptive literature of these experiences accords quite remarkably with my own.

Almost invariably, my experiments with psychedelics have had four dominant characteristics. I shall try to explain them-in the expectation that the reader will say, at least of the second and third, "Why, that's obvious! No one needs a drug to see that." Quite so, but every insight has degrees of intensity. There can be obviousi and obvious2-and the latter cones on with shattering clarity, mamifesting its inplications in every sphere and dinension of our existence.

The first characteristic is a slowing down of time, a concentration in the present. One's normally compulsive concern for the future decreases, and one beconies aware of the enormous importance and interest of what is happening at the moment. Other people, going about their business on (1959).

2 An excellent anthology of such experiences is R. JOHNSON, WATCHER ON THE HIILS 
the streets, seem to be slightly crazy, failing to realize that the wlole point of life is to be fully aware of it as it happens. One therefore relaxes, almost luxuriously, into studying the colors in a glass of water, or in listening to the now highly articulate vibration of every note played on an oboe or sung by voice.

From the pragmatic standpoint of our culture, sucl an attitude is very bad for business. It might lead to improvidence, lack of foresight, diminished sales of insurance policies, and abandoned savings accounts. Yet this is just the corrective that our culture needs. No one is more fatuously impractical than the "successful" executive who spends his whole hife absorbed in frantic paperwork with the objective of retiring in comfort at sixty-five, when it will all be too late. Only those who have cultivated the art of hiving completely in the present have any use for making plans for the future, for when the plans inature they will be able to enjoy the results. "Tomorrow never comes." I have never yet lieard a preacher urging his congregation to practice that section of the Sermon on the Mount whicl begins, "Be not anxious for the norrow. ..." The truth is that people who live for the future are, as we say of the insane, "not quite all there"-or here: by over-eagerness they are perpetually missing the point. Foresight is bought at the price of anxiety, and, when overused it destroys all its own advantages.

The second characteristic I will call awareness of polarity. This is the vivid realization that states, things, and events which we ordinarily call opposite are interdependent, like back and front or the poles of a magnet. By polar awareness one sees that things which are explicitly different are implicity one: self and other, subject and object, left and riglit, male and female - and then, a little more surprisingly, solid and space, figure and background, pulse and interval, saints and sinners, and police and criminals, ingroups and outgroups. Each is definable ouly in terms of the other, and they go together transactionally, like buying and selling, for there is no sale without a purchase, and no purchase without a sale. As this awareness becomes increasingly intense, you feel that you yourself are polarized with the external universe in such a way that you imply eacli other. Your pusin is its pull, and its push is your pull-as when you move the steeringwheel of a car. Are you pushing it or pulling it?

At first, this a very odd sensation, not unlike hearing your own voice played back to you on an electronic system immediately after you liave spoken. You become confused, and wait for $i t$ to go on! Similarly, you feel that you are something being done by the universe, yet that the universe is equally something being done by you-which is true, at least in the neurological sense that the peculiar structure of our brains translates the sun into light and air vibrations into sound. Our normal sensation of rela- 
tionship to the outside world is that sometimes I push it, and sometimes it pushes me. But if the two are actually one, where does action begin and responsibility rest? If the universe is doing me, how can I be sure that, two seconds hence, I will still remember the English language? If I anI doing it, how can I be sure that, two seconds hence, my brain will know how to turn the sun into light? From such unfamiliar sensations as these the psychedelic experience can generate confusion, paranoia, and terroreven though the individual is feeling his relationship to the world exactly as it would be described by a biologist, ecologist, or physicist, for he is feeling himself as the unified field of organism and environment.

The third characteristic, arising from the second, is awareness of relativity. I see that I am a link in an infinite hierarchy of processes and beings, ranging from molecules through bacteria and insects to human beings, and, maybe, to angels and gods - a hierarchy in which every level is in effect the same situation. For example, the poor man worries about money while the rich man worries about his health: the worry is the same, but the difference is in its substance or dimension. I realize that fruit flies inust think of themselves as people, because, like ourselves, they find themselves in the middle of their own world-with immeasurably greater things above and smaller things below. To us, they all look alike and seem to have no personality - as do the Chinese when we have not hived among then. Yet fruit flies must see just as many subtle distinctions among themselves as we among ourselves.

From this it is but a short step to the realization that all forms of hife and being are simply variations on a single theme: we are all in fact one being doing the same thing in as many different ways as possible. As the French proverb goes, plus ça change, plus c'est la même chose-"the more it varies, the more it is one." I see, further, that feeling threatened by the inevitability of death is really the same experience as feeling alive, and that as all beings are feeling this everywhere, they are all just as much " $T$ " as myself. Yet the " $T$ " feeling, to be felt at all, must always be a sensation relative to the "other"- to something beyond its control and experience. To be at all, it must begin and end. But the intellectual jump which mystical and psychedelic experience make here is in enabling you to see that all these myriad I-centers are yourself-not, indeed, your personal and superficially conscious ego, but what Hindus call the paramatman, the Self of all selves. ${ }^{3}$ As the retina enables us to see countless pulses of

3 Thus Hinduism regards the universe, not as an artifact, but as an immense drama in which the One Actor (the paramatman or brahman) plays all the parts, which are his (or "its") masks or personae. The sensation of being only this one particular self, John Doe, is due to the Actor's total absorption in playing this and every other part. For fuller exposition, see S. Radiakrishnan, The Hindu VIEW of Life (1927); H, ZnMamer, Philosophass OF INDIA 355-463 (1951). A popular version is in A. WatTs, THE BOOK: ON tמE TaBoo Agatist KNowing Who You ARe (1966). 
energy as a single light, so the mystical experience shows us innumerable individuals as a single Self.

The fourth characteristic is awareness of eternal energy, often in the form of intense white light, which seems to be both the current in your nerves and that mysterious $e$ which equals $m c^{2}$. This may sound hike megalomania or delusion of grandeur-but one sees quite clearly that all existence is a single energy, and that this energy is one's own being. Of course there is death as well as hife, because energy is a pulsation, and just as waves must have both crests and troughs the experience of existing must go on and off. Basically, therefore, there is simply nothing to worry about, because you yourself are the eternal energy of the universe playing hide-and-seek (off-and-on) with itself. At root, you are the Godhead, for God is all that there is. Quoting Isaiah just a little out of context: "I am the Lord, and there is none else. I form the light and create the darkness: I make peace, and create evil. I, the Lord, do all these things." This is the sense of the fundamental tenet of Hinduisn, Tat tvam asi- "THAT (i.e., "that subtle Being of whicl this whole universe is composed") art thou." A classical case of this experience, from the West, is in Tennyson's Memoirs:

A kind of waking trance I have frequently had, quite up from boyhood, when I have been all alone. This has generally come upon me thro' repeating my own name two or three times to myself silently, till all at once, as it were out of the intensity of the consciousness of individuality, the individuality itself seemed to dissolve and fade away into boundless being, and this not a confused state, but the clearest of the clearest, the surest of the surest, the weirdest of the weirdest, utterly beyond words, where death was an almost laughable impossibility, the loss of personahity (if so it were) seeming no extinction but the only true life. ${ }^{8}$

Obviously, these characteristics of the psycledelic experience, as I have known it, are aspects of a single state of consciousness-for I have been describing the same thing from different angles. The descriptions atteinpt to convey the reality of the experience, but in doing so they also suggest some of the inconsistencies between such experience and the current values of society.

II

OPPOSITION TO PSYCHEDELIC DRUGS

Resistence to allowing use of psychedehic drugs originates in both rehious and secular values. The difficulty in describing psychedehic experi-

4 Isaiali 45: 6, 7 .

5 Chandogya Upanishad 6.15.3.

B 1 ALFRED LORD TENNYSON, A MEMOIR BY HIS SON 320 (1898). 
ences in traditional religious terms suggests one ground of opposition. The Westerner must borrow such words as samadhi or moksha from the Hindus, or satori or kensho from the Japanese, to describe the experience of oneness with the universe. We have no appropriate word because our own Jewish and Clristian theologies will not accept the idea that man's inmost self can be identical with the Godhead, even though Christians may insist that this was true in the unique instance of Jesus Christ. Jews and Christians think of God in political and monarchical terms, as the supreme governor of the universe, the ultimate boss. Obviously, it is both socially unacceptable and logically preposterous for a particular individual to claim that he, in person, is the omnipotent and omniscient ruler of the world-to be accorded suitable recognition and honor.

Such an imperial and kingly concept of the ultimate reality, however, is neither necessary nor universal. The Hindus and the Chinese have no difficulty in conceiving of an identity of the self and the Godiread. For most Asians, other than Muslims, the Godliead moves and manifests the world in much the same way that a centipede manipulates a hundred legs -spontaneously, without deliberation or calculation. In other words, they conceive the universe by analogy with an organisn as distinct from a mechanism. They do not see it as an artifact or construct under the conscious direction of some supreme technician, engineer, or architect.

If, however, in the context of Clristian or Jewisl tradition an individual declares himself to be one with God, he must be dubbed blasplenous (subversive) or insane. Such a mystical experience is a clear threat to traditional religious concepts. The Judaeo-Christian tradition has a monarchical image of God, and monarchs, who rule by force, fear nothing more than insubordination. The Church lias therefore always been highly suspicious of mystics because they seem to be insubordinate and to claim equality or, worse, identity with God. For this reason John Scotus Erigena and Meister Eckhart were condemned as heretics. This was also why the Quakers faced opposition for their doctrine of the Inward Liglt, and for their refusal to remove hats in church and in court. A few occasional mystics may be all right so long as they watch their language, like St. Teresa of Avila and St. John of the Cross, who maintained, shall we say, a meta-physical distance of respect between themselves and their heavenly King. Nothing, however, could be more alarming to the ecclesiastical hierarchy than a popular outbreak of mysticism, for this might well amount to setting up a democracy in the kingdom of lieaven - and such alarm would be shared equally by Catholics, Jews, and fundamentalist Protestants.

The Monarchical image of God with its implicit distaste for religious insubordination has a more pervasive impact than many Christians might 
admit. The thrones of kings have walls immediately behind them, and all who present themselves at court must prostrate themselves or kneel because this is an awkward position from which to make a sudden attack. It has perhaps never occurred to Christians that when they design a church on the model of a royal court (basilica) and prescribe churcli ritual, they are implying that God, like a human monarch, is afraid. This is also implied by flattery in prayers:

O Lord our heavenly Father, high and mighty, King of kings, Lord of lords, the only Ruler of princes, who dost from thy throne behold all the dwellers upon earth: most heartily we beseech thee with thy favor to behold .... ${ }^{7}$

The Western man who claims consciousness of oneness with God or the universe thus clashes with his society's concept of religion. In most Asian cultures, however, sucl a man will be congratulated as having penetrated the true secret of life. He has arrived, by cliance or by some such discipline as Yoga- or Zen-meditation, at a state of consciousness in which he experiences directly and vividly what our own scientists know to be true in theory. For the ecologist, the biologist, and the physicist know (but seldom feel) that every organism constitutes a single field of behavior, or process, with its environment. There is no way of separating what any given orgamsm is doing from what its environment is doing, for which reason ecologists speak not of organisms in environments but of organismenvironments. Thus the words "I" or "self" should properly mean what the whole universe is doing at this particular "here-and-now" called John Doe.

The kingly concept of God makes identity of self and God, or self and universe, inconceivable in Western religious terms. The difference between Eastern and Western concepts of man and his universe, however, extends beyond strictly religious concepts. The Western scientist may rationally perceive the idea of organism-environment, but he does not ordinarily feel this to be true. By cultural and social conditioning, he has been hypnotized into experiencing himself as an ego-as an isolated center of consciousness and will inside a bag of skin, confronting an external and alien world. We say, "I came into this world." But we did nothing of the kind. We came out of it in just the same way that fruit comes out of trees. Our galaxy, our cosnios, "peoples" in the same way that an apple tree "apples."

Such a vision of the universe clashes with the idea of a monarclical God, with the concept of the separate ego, and even with the secular, atheist-agnostic mentahty, which derives its common sense from the mythol-

7 A Prayer for the King's Majesty, Order for Morning Prayer, Boor on CoMmoN Prayser (Church of England 1904). 
ogy of nineteeth-century scientism. According to this view, the universe is a mindless mechanism and man a sort of accidental micro-organism infesting a minute globular rock which revolves about an unimportant star on the outer fringe of one of the minor galaxies. This "putdown" theory of man is extremely common among such quasi-scientists as sociologists, psychologists, and psychiatrists, nosst of whom are still thinking of the world in terms of Newtonian mechanics, and have never really caught up with the ideas of Einstein and Bohr, Oppenheimer and Schrödinger. Thus to the ordinary institutional-type psycharist, any patient who gives the least hint of mystical or rehigious experience is automatically diagnosed as deranged. From the standpoint of the nuechanistic religion he is a heretic and is given electroshock therapy as an up-to-date form of thumbscrew and rack. And, incidentally, it is just this kind of quasi-scientist who, as consultant to government and law enforcement agencies, dictates official pohicies on the use of psychedehic chemicals.

Inability to accept the mystic experience is more than an intellectual handicap. Lack of awareness of the basic unity of orgamsm and environment is a serious and dangerous hallucination. For in a civilization equipped with immense technological power, the sense of ahenation between man and nature leads to the use of technology in a lostile spirit-to the "conquest" of nature instead of intelligent cooperation with nature. The result is that we are eroding and destroying our environment, spreading Los Angelization instead of civilization. This is the major threat overhanging Western, technological culture, and no amount of reasoning or doompreaching seems to help. We simply do not respond to the prophetic and morahizing techniques of conversion upon which Jews and Christians have always relied. But people have an obscure sense of what is good for them-call it "unconscious self-healing," "survival instinct," "positive growth potential," or what you will. Among the educated young there is therefore a startling and unprecedented interest in the transformation of human consciousness. All over the Western world publishers are selling milhons of books dealing with Yoga, Vedanta, Zen Buddhism, and the chemical mysticism of psychedelic drugs, and I have come to beheve that the whole "hip" subculture, however misguided in some of its manifestations, is the earnest and responsible effort of young people to correct the self-destroying course of industrial civilization.

The content of the mystical experience is thus inconsistent with both the religious and secular concepts of traditional Western thought. Moreover, mystical experiences often result in attitudes which threaten the authority not only of estabhished churches, but also of secular society. Unafraid of death and deficient in worldly ambition, those who have undergone nrystical experiences are impervious to threats and promises. More- 
over, their sense of the relativity of good and evil arouses the suspicion that they lack both conscience and respect for law. Use of psychedelics in the United States by a literate bourgeoisie means that an important segment of the population is indifferent to society's traditional rewards and sanctions.

In theory, the existence within our secular society of a group whicli does not accept conventional values is consistent with our political vision. But one of the great problems of the United States, legally and politically, is that we have never quite had the courage of our convictions. The Republic is founded on the marvellously sane principle that a human community can exist and prosper only on a basis of mutual trust. Metaphysically, the American Revolution was a rejection of the dogma of Origmal Sin, which is the notion that because you cannot trust yourself or other people, there must be some Superior Authority to keep us all in order. The dogma was rejected because if it is true that we cannot trust ourselves and others, it follows that we cannot trust the Superior Authority whicl we ourselves conceive and obey and that the very idea of our own untrustworthiness is unreliable!

Citizens of the United States believe, or are supposed to believe, that a republic is the best form of government. Yet, vast confusion arises from trying to be republican in politics and monarchist in religion. How can a republic be the best form of government if the universe, heaven, and hell are a monarchy? ${ }^{8}$ Tlius, despite the theory of government by consent, based upon mutual trust, the peoples of the United States retain, from the authoritarian backgrounds of their religions or national origins, an utterly naive faith in law as some sort of supernatural and paternalistic power. "There ought to be a law against it!" Our law-enforcement officers are therefore confused, hindered, and bewildered-not to mention corrupted-by being asked to enforce sumptuary laws, often of ecclesiastical origin, whicl vast numbers of people have no intention of obeying and whicl, in any case, are immensely difficult or simply impossible to enforce-for example, the barring of anything so undetectable as LSD-25 from international and interstate commerce.

Finally, there are two specific objections to use of psychedehic drugs. First, use of these drugs may be dangerous. However, every worthwhile exploration is dangerous-climbing mountains, testing aircraft, rocketing into outer space, skin-diving, or collecting botanical specimens in jungles.

8 Thus, until quite recently, belief in a Supreme Being was a legal test of valid conscientious objection to military service. The implication was that the individual objector found himself bound to obey a higher echelon of command than the President and Congress. The analogy is military and monarchical, and therefore objectors who, as Buddhists or naturalists, held an organic theory of the universe often had difficulty in obtaining recognition. 
But if you value knowledge and the actual delight of exploration more than mere duration of uneventful hfe, you are willing to take the risks. It is not really healthy for monks to practice fasting, and it was hardly hygienic for Jesus to get himself crucified, but these are risks taken in the course of spiritual adventures. Today the adventurous young are taking risks in exploring the psyche, testing their mettle at the task just as, in times past, they have tested it-more violently-in hunting, dueling, lot-rod racing, and playing football. What they need is not proluibitions and policenien but the most intelligent encouragenent and advice that can be found.

Second, drug use may be critized as an escape from reality. However, this criticism assumes unjustly that the mystical experiences themselves are escapist or unreal. LSD, in particular, is by no means a soft and cushy escape from reality. It can very easily be an experience in which you have to test your soul against all the devils in hell. For me, it has been at times an experience in which I was at once completely lost in the corridors of the mind and yet relating that very lostness to the exact order of logic and language, simultaneously very mad and very sane. But beyond these occasional lost and insane episodes, there are the experiences of the world as a system of total harmony and glory, and the discipline of relating these to the order of logic and language must somehow explain how what William Blake called that "energy which is eternal delight" can consist with the misery and suffering of everyday hife."

The undoubted mystical and rehgious intent of most users of the psycliedelics, even if some of these substances should be proved injurious to physical health, requires that their free and responsible use be exempt from legal restraint in any repubhic whicl maintains a constitutional separation of Cluurch and State. ${ }^{10}$ To the extent that mystical experience

${ }^{9}$ This is discussed at length in A. Watts, The Joyous Cosmorogy: Adventures IN TIEE Chemistry of Consctousness (1962).

10 "Responsible" in the sense that such substances be taken by or administered to consenting adults only. The user of cannabis, in particular, is apt to have peculiar difficulties in establishing his "undoubted inystical and religious intent" in court. Having committed so loathsome and serious a felony, his chances of clemency are better if he assumes a repentant demeanor, which is quite inconsistent with the sincere belief that his use of cannabis was rehigious. On the other hand, if he insists unrepentantly that lie looks upon such use as a rehious sacrament, many judges will declare that they "dislike his attitude," finding it truculent and lacking in appreciation of the gravity of the crime, and the sentence will be that much harsher. The accused is therefore put in a "double-bind" situation in which he is "damned if he does, and damned if he doesn't." Furthermore, rehigious integrity-as in conscientious objection-is generally tested and established by membership is some church or rehigious organization with a substantial following. But the felonious status of cannabis is such that grave suspicion would be cast upon all individuals forming such an organization, and the test cannot therefore be fulfilled. It is generally forgotten that our guarantees of religious freedom were designed to protect precisely those who were not members of established 
conforms with the tradition of genuine religious involvement, and to the extent that psychedelics induce that experience, users are entitled to some constitutional protection. Also, to the extent that research in the psycliology of religion can utilize such drugs, students of the human mind must be free to use them. Under present laws, $I$, as an experienced student of the psychology of religion, can no longer pursue research in the field. This is a barbarous restriction of spirtual and intellectual freedom, suggesting that the legal system of the United States is, after all, in tacit alliance with the monarchical theory of the universe and will, therefore, prohibit and persecute religious ideas and practices based on an orgamic and unitary vision of the universe. ${ }^{11}$

denominations, but rather such screwball and (then) subversive individuals as Quakers, Shakers, Levellers, and Anabaptists. There is little question that those wlio use cannabis, or other psychedelics, with religious intent are now members of a persecuted religion which appears to the rest of society as a grave menace to "mental liealth," as distinct from the oldfashioned "immortal soul." But it's the same old story.

11 Amerindians belonging to the Native American Cliurch, who employ the psychedelic peyote cactus in their rituals, are firmly opposed to any government control of this plant, even if they should be guaranteed the right to its use. They feel that peyote is a natural gift of God to mankind, and especially to natives of the land where it grows, and that no government bas a rigbt to interfere with its use. The same argument might be made on behalf of cannabis, or the mushroom psilocybe mexicana Heim. All these things are natural plants, not processed or synthesized drugs, and by what authority can individuals be prevented from eating them? There is no law against eating or growing the mushroom amanita pantherina, even though it is fatally poisonous and only experts can distinguish it from a common edible mushroom. This case can be made even from the standpoint of believers in the monarchical universe of Judaism and Christianity, for it is a basic principle of both religions, derived from Genesis, that all natural substances created by God are inherently good, and that evil can arise only in their misuse. Thus laws against mere possession, or even cultivation, of these plants are in basic conflict with Biblical principles. Criminal conviction of those who employ these plants should be based on proven misuse. "And God said, 'Behold, I have given you every herb bearing seed, which is upon the face of all the earth, and every tree, in the which is the fruit of a tree yielding seed; to you it shall be for meat . . . . And God saw every thing that he had made, and, behold, it was very good." Genesis 1:29, 31. 